\title{
Oviposition behavior of wild Zabrotes subfasciatus (Coleoptera, Chrysomelidae) females deprived of the host Phaseolus vulgaris (Fabaceae)
}

\author{
Luiza A. A. Sperandio \& Fernando S. Zucoloto
}

Departamento de Biologia, Faculdade de Filosofia, Ciências e Letras de Ribeirão Preto, Universidade de São Paulo, Av. Bandeirantes, 3900, 14040-901 Ribeirão Preto, São Paulo, Brazil. (zucoloto@ ffclrp.usp.br)

\begin{abstract}
The insects oviposition behavior is fundamental to study population dynamics, life history evolution, insect-plant and parasitoid-host interactions. Zabrotes subfasciatus (Boheman, 1833) females oviposition behavior in the presence and absence of a host is unknown. The main objective of this study was to describe in detail the oviposition behavior of host deprived or non-deprived females, and observe how the several situations of deprivation (days without host) influence oviposition. Six groups were assembled, three deprived of the host (for 2, 5 and 8 days) and three control groups (with host), each containing one newly-emerged couple (0-24h) of wild Z. subfasciatus, The non-deprived (control) groups received the hosts every day (5 bean seeds Phaseolus vulgaris (Fabaceae)) and the others were deprived for 2,5 and 8 days, respectively. For each group 12 repetitions were made. Consequently, 12 couples were host deprived during two days, 12 couples were host deprived during five days and 12 couples were host deprived during eight days. When the seeds of the deprived groups were added the experiments started. There was a control group for each deprived group. The experiments and the insects were maintained at constant temperature $29 \pm 2^{\circ} \mathrm{C}$ and $70-80 \%$ relative humidity. At 15 minutes interval, the number of times the females manifested the different categories of behavior was observed (frequency). The behavior categories were: rest inside the box, locomotion, resource exploration (seeds), copulation and oviposition. The deprived females stayed most of the time in contact with the host to carry out oviposition, while the non-deprived (control) females spent most of the time at rest. This was observed in all the deprivation times. The results show that host deprivation influences the oviposition behavior of the studied species and also shows the flexibility in the oviposition strategies that these females present when the environment changes (absence and presence of resources).
\end{abstract}

KEYWORDS. Host deprivation, oviposition behavior, Bruchinae.

RESUMO. Comportamento de ovoposição de fêmeas selvagens de Zabrotes subfasciatus (Coleoptera, Chrysomelidae) privadas do hospedeiro Phaseolus vulgaris (Fabaceae). O comportamento de oviposição de insetos é fundamental em pesquisas de dinâmica populacional, evolução da história de vida, interações inseto-planta e parasitóide-hospedeiro. O comportamento de oviposição de fêmeas de Zabrotes subfasciatus (Boheman, 1833) na presença e ausência de hospedeiro é desconhecido. O principal objetivo deste trabalho foi verificar de que modo as várias situações de privação temporária de hospedeiro influenciam a oviposição. Foram montados 6 grupos, sendo 3 privados de hospedeiro (por 2, 5 e 8 dias) e 3 controles (com hospedeiro), cada um contendo um casal recém-emergido (0-24 h) de $Z$. subfasciatus selvagem. Apenas os grupos controles receberam os hospedeiros todos os dias (5 sementes de feijão, Phaseolus vulgaris (Fabaceae)); os demais ficaram sem o hospedeiro por 2, 5 e 8 dias, respectivamente. Para cada grupo, 12 repetições foram realizadas. Desta forma, 12 casais foram privados do hospedeiro por 2 dias, 12 casais foram privados do hospedeiro por 5 dias e 12 casais foram privados do hospedeiro por 8 dias. Quando as sementes dos feijões foram adicionadas nos grupos privados, as observações iniciavam. Havia um grupo controle para cada grupo privado. Os experimentos e os insetos foram mantidos a uma temperatura constante de $29 \pm 2^{\circ} \mathrm{C}$ e $70-80$ :\% umidade relativa. A cada 15 minutos, foi observado o número de vezes que as fêmeas manifestavam as diferentes categorias de comportamento (frequência). As categorias de comportamento foram: repouso dentro da caixa, locomoção, exploração dos recursos (sementes), cópula e oviposição. As fêmeas privadas ficaram a maior parte do tempo em contato com o hospedeiro para realizar a oviposição, enquanto as controles ficaram a maior parte do tempo em repouso. Isto foi observado em todos os tempos de privação. Os resultados mostram que a privação de hospedeiro influencia o comportamento de oviposição da espécie estudada e também mostra a flexibilidade nas estratégias de oviposição que estas fêmeas apresentam quando o ambiente se altera (ausência e presença de recursos).

PALAVRAS-CHAVE. Privação de hospedeiro, comportamento de oviposição, Bruchinae.

In phytophagous holometabolous insects, selection of an adequate site for oviposition is determinant in the choice of the host plant for the immature insects, mainly if the offspring is unable to search additional hosts before using the nutritive resources selected by the mother (Singer, 1986; RENwiCK, 1989; MAYHEW, 1997). The oviposition process involves a consecutive series of behaviors which demand for each individual case the presence of an adequate stimulus in order that a satisfactory response occurs (HsiaO, 1985).

Zabrotes subfasciatus (Boheman, 1833) is a serious pest of stored beans (MеIк \& DoBIE, 1986), known as "caruncho do feijão" (bean worm). Zabrotes subfasciatus is found in tropical and subtropical regions of the Central and South Americas and is one of the main pests of Phaseolus vulgaris (Fabaceae) during storage (HAINES,
1991). Despite the importance of the species, relativelly little is known of its biology and most references to it are based on numerous assumptions and analogies with other, better known, of the Bruchinae subfamily (CRedLand \& Dendy, 1992).

In this species, the eggs are directly laid on the seeds and the immatures are unable to shift and search another alimentary source (CREDLAND \& DENDY, 1992). After eclosion, the larvae perforate the seed tegument and complete their development eating only the contente of a seed (Southgate, 1979; Credland \& Dendy, 1992). During storage, the adults may produce many generations without any food (JOHNSON, 1989).

In the Bruchinae subfamily, the adult weevils usually deposit and adhere their eggs in the bean seed surface apparently at random, but the Z . subfasciatus 
females lay some of their eggs in the seed surface in groups of 2, 3, 4 or more eggs (UTIDA, 1967; SARI et al., 2003; Sperandio \& Zucoloto, 2004). Therefore, as the adults in general do not feed themselves (CARVALHO \& Rossetto, 1968) the adult females "determine" the amount of available resources for each of the descendants in potential (DENDY \& CREDLAND, 1991); probably, they develop the behavior of maximizing their fitness, for instance, distributing a higher amount of eggs in the largest hosts (YANG \& HoRnG, 2002; COPE \& Fox, 2003; SZENTESI, 2003).

The egg load of females (number of mature ovules in the ovaries) is considered an important factor in relation to oviposition behavior. Pro-ovigenic insects as $Z$. subfasciatus emerge with all eggs mature (MINKENBERG et al., 1992). Host deprivation immediately after adult emergence has different consequences for pro-ovigenic and synovigenic species because egg resorption might occur during the period of host deprivation (FLEURY \& BoulÉtReAu, 1993).

Deprivation of the host is frequently used to investigate the effect of the eggs load on the oviposition behavior (FITT, 1986; HARRIS \& MILLER, 1988), however, the effect of deprivation itself on the insects oviposition behavior has received little attention (SADEGUI \& GILBERT, 2000).

Experiments with host deprivation for wild $Z$. subfasciatus, using $P$. vulgaris variety Rosinha as host, have shown that the temporary deprivation period (2 to 10 days) of the host alters the oviposition peak for the $1^{\text {st }}$ day after its inclusion, as also aggregates more eggs in relation to the $P$. vulgaris seeds (SPERANDIO \& ZuCOLOTO, 2004). However, the frequence the females manifested different kinds of behavior was not observed.

The aim of this study was to describe in detail the oviposition behavior of host deprived or non-deprived females, and observe how the several situations of deprivation (days without host) influence oviposition.

\section{MATERIAL AND METHODS}

The study was carried out in the Insect Nutrition and Feeding Behavior Laboratory, Biology Department, Faculdade de Filosofia, Ciências e Letras de Ribeirão Preto, SP, Brazil. Seeds containing Z. subfasciatus were collected in Ribeirão Preto $\left(21^{\circ} 05^{\prime}-21^{\circ} 15^{\prime} S\right.$ and $47^{\circ} 50$ ' $\left.47^{\circ} 55^{\prime} \mathrm{W}\right)$ warehouses. The variety of the seeds collected to obtain the insects was always the same (carioquinha). The seeds were taken to the laboratory and placed in acrylic sealed boxes $(11 \times 11 \times 3 \mathrm{~cm})$ until the emergence of adults. Afterwards, they were transferred to identical compartments containing bean seeds, variety Rosinha, to compose breeding in laboratory. After a generation in the laboratory the experiments started. The $Z$. subfasciatus populations were wild, since they were always collected in warehouses.

The experiments and the insects were maintained in wooden ovens $(90 \times 50 \times 30 \mathrm{~cm})$ equipped with a thermostat and electric resistance to maintain constant temperature $29 \pm 2^{\circ} \mathrm{C}$ and R.H. 70-80 \%. The experiments were conducted in acrylic sealed boxes $(11 \times 11 \times 3 \mathrm{~cm})$. The seeds were maintained in a freezer at $-18^{\circ} \mathrm{C}$ for 48 hours to avoid any kind of predation and, before starting the experiments, they were placed in ovens at $29 \pm 2{ }^{\circ} \mathrm{C}$ for 48 hours to maintain an adequate temperature for the Z. subfasciatus population.

The insects used in the experiments were newly emerged (0-24 hour-old). PAJNI \& JABBAL (1986) observed that males and females newly emerged from Phaseolus lunatus seeds (Rajmash), are in general able to copulate after one hour and the females are able oviposit from 2 to 30 hours after copulating, at a $30^{\circ} \mathrm{C}$ temperature and 70 $\%$ R.H.

Only one variety of bean seeds ( $P$. vulgaris var. Rosinha) was used. This variety was chosen because it is common in the region where those wild insect populations were collected and, therefore, no rejection problems should arise as concerned the host (TEIXEIRA \& ZuCOLOTO, 2003).

Six groups were assembled, three deprived of the host (for 2, 5 and 8 days) and three control groups (with host), each containing one newly-emerged couple (0-24h) of wild Z. subfasciatus. The non-deprived (control) groups received the hosts every day ( 5 bean seeds $P$. vulgaris) and the others were deprived for 2,5 and 8 days, respectively. For each group 12 repetitions were made. Consequently, 12 couples were host deprived during two days, 12 couples were host deprived during five days and 12 couples were host deprived during eight days. When the seeds of the deprived groups were added the experiments started. There was a control group for each deprived group. Four boxes were assembled at the same time, 2 from the control group and 2 from the deprived group. If an insect died during the experiment, it was discarded without reposition. The repetitions were not always carried out at the same moment, however, there always was a correspondent control group to be simultaneously observed with the deprived group.

The females of each group were observed under a stereomicroscope in days corresponding to the above mentioned deprivations, from $10 \mathrm{a} . \mathrm{m}$. to $3 \mathrm{p} . \mathrm{m}$. This period of time was chosen because the majority of the Bruchinae subfamily is diurnal (SouthGaTe, 1979). The number of times the females remained in the different behavior categories was observed: at rest in the box, locomotion, exploration of the resources (seeds), copulation and oviposition, each 15 minutes. Locomotion was defined as the displacement of the females inside the boxes without touching the seeds and exploration as the displacement of the females on the seeds.

To show what happened to the females along the observation period, the average frequencies of each female activity were calculated. The average frequency of each behavior in each group was defined dividing the sum of all absolute frequencies by the total number of females.

The Kolmogorov-Smirnov test was used to verify normality. As only some groups presented a normal distribuition of the data, the Mann-Whitney nonparametric test was used for comparisons between 2 groups. These tests were conducted using the SigmaStat program for Windows Version 2.03- Jandel Corporation. The level of significance was at $5 \%$. 


\section{RESULTS}

Although some of the control females presented different behaviors in the same moment of observation, most of them presented characteristics in common: they remained most of the time at rest in the box, motionless. This was statistically different from the deprived females (Tabs. I, II, III) that spent most of the time laying eggs. Most of the control females also moved inside the box without touching the seeds, but in lower frequency and showed statistical differences as concerned the deprived females only with 8 days of host deprivation (Tab. III). The control and deprived females walked on the seeds, exploring them repetitively with the antennas extremity and the control females explored less in relation to the deprived females with 5 days host deprivation only (Tab. II). They rested the ovipositor on the seeds, moistening them, however they did not lay the eggs. Or they stuck themselves to the seed trying to lay the eggs, but as the males approached and touched them (trying to copulate) they left the seed. Copulation was observed in the control and deprived females and the former copulated less (with statistical difference) only in the group of 2 days host deprivation (Tab. I).

As concerns ovipositions, they were much more frequent in the deprived females with statistical differences in all the groups (Tabs. I, II, III). The aggregation of eggs was very rare in the control females groups (during the time of observation of the experiments) and in the deprived females was very common. The deprived females remained stuck to the seed. Afterwards, they walked on it, leaving the ovipositor in contact with

Table I. Average frequence of the 5 different kinds of behavior of wild control and host deprived for 2 days Zabrotes subfasciatus (Boheman, 1833) females. Number of couples: 10 (control) and 9 (deprived)*. Averages followed by different letters in the same line indicate that there was a statistical difference between the groups $(\mathrm{p}<0.05$, Mann-Whitney test, $\mathrm{a}=0.05)$ (*, two control and three deprived females died before the experiment started).

\begin{tabular}{lcc}
\hline Behavior & $\begin{array}{c}\text { Control females } \\
(\% \text { of occurrence })\end{array}$ & $\begin{array}{c}\text { Deprived females } \\
(\% \text { of occurrence })\end{array}$ \\
\hline At rest in the box & $12.8 \pm 4.4 \mathrm{a}$ & $4.9 \pm 3.8 \mathrm{~b}$ \\
Locomotion & $3.5 \pm 3.6 \mathrm{a}$ & $2.1 \pm 2.8 \mathrm{a}$ \\
Exploration & $0.5 \pm 0.7 \mathrm{a}$ & $1.0 \pm 1.1 \mathrm{a}$ \\
Copulation & $0.7 \pm 1.3 \mathrm{a}$ & $1.8 \pm 1.7 \mathrm{~b}$ \\
Oviposition & $2.5 \pm 2.6 \mathrm{a}$ & $10.2 \pm 5.1 \mathrm{~b}$ \\
\hline
\end{tabular}

Table II. Average frequence of the 5 different kinds of behavior of wild control and host deprived for 5 days Zabrotes subfasciatus (Boheman, 1833) females. Number of couples: 12 (Control) and 12 (Deprived). Averages followed by different letters in the same line indicate that there was a statistical difference between the groups ( $\mathrm{p}<0.05$, Mann-Whitney test, $\alpha=0.05)$.

\begin{tabular}{lcc}
\hline Behavior & $\begin{array}{c}\text { Control females } \\
(\% \text { of occurrence })\end{array}$ & $\begin{array}{c}\text { Deprived females } \\
(\% \text { of occurrence })\end{array}$ \\
\hline At rest in the box & $16.2 \pm 2.4 \mathrm{a}$ & $4.6 \pm 5.2 \mathrm{~b}$ \\
Locomotion & $1.5 \pm 1.5 \mathrm{a}$ & $0.8 \pm 1.3 \mathrm{a}$ \\
Exploration & $0 \mathrm{a}$ & $1.9 \pm 2.3 \mathrm{~b}$ \\
Copulation & $0.9 \pm 1.3 \mathrm{a}$ & $0.5 \pm 0.9 \mathrm{a}$ \\
Oviposition & $1.4 \pm 1.1 \mathrm{a}$ & $12.2 \pm 5.6 \mathrm{~b}$ \\
\hline
\end{tabular}

Table III. Average frequence of the 5 different kinds of behavior of wild control and host deprived for 8 days Zabrotes subfasciatus (Boheman, 1833) females. Number of couples: 12 (control) and 12 (deprived). Averages followed by different letters in the same line indicate that there was a statistical difference between the groups ( $\mathrm{p}<0.05$, Mann-Whitney test, $\alpha=0.05$ ).

\begin{tabular}{lcc}
\hline Behavior & $\begin{array}{c}\text { Control females } \\
(\% \text { of occurrence })\end{array}$ & $\begin{array}{c}\text { Deprived females } \\
(\% \text { of occurrence })\end{array}$ \\
\hline At rest in the box & $13.7 \pm 4.8 \mathrm{a}$ & $7.4 \pm 8.0 \mathrm{~b}$ \\
Locomotion & $2.2 \pm 2.8 \mathrm{a}$ & $0.2 \pm 0.4 \mathrm{~b}$ \\
Exploration & $0.7 \pm 1.4 \mathrm{a}$ & $0.6 \pm 0.8 \mathrm{a}$ \\
Copulation & $3.0 \pm 4.9 \mathrm{a}$ & $0.8 \pm 1.5 \mathrm{a}$ \\
Oviposition & $0.6 \pm 1.2 \mathrm{a}$ & $11.0 \pm 7.0 \mathrm{~b}$ \\
\hline
\end{tabular}

the seed (as they walked). Then, they stopped in a specific region of the seed and tried to lay the eggs. Several times there were only tentatives until oviposition takes place. Soon after that, they stayed still on the egg, touched it with the antennas, the labial palps and the anterior legs. They moved a little using the anterior legs in front of the egg, stayed still and tried again to lay eggs near the first egg.

\section{DISCUSSION}

The control females spent most of the time at rest. This coincides with RosenHeIM \& Rosen (1991) who observed at $30^{\circ} \mathrm{C}$ and $70 \% \mathrm{R}$. H. that the Aphytis lingnanensis (Compere, 1955) parasitoid females that possessed smaller loads of eggs spent most of the time at rest, and were not host deprived. However, the deprived females in this study spent most of the time in contact with the host and laid eggs with higher frequency than the control ones.

This can be due to the fact that the deprived females probably contained a large load of eggs in their ovaries (SPERANDio \& Zucoloto, 2004); this may have led the females to oviposit therefore avoiding a more intense resorption of their eggs, since in pro-ovigenic species, egg resorption can markedly reduce fecundity since eggs are not replenished (Fleury \& Bouletreau, 1993). Notwithstanding, RosenHEIM \& Rosen (1991) shows that the manipulation period with the host was inversely related to the load of eggs in the parasitoid $A$. lingnanensis, as well as of each component of the activities that comprise host manipulation, including preparation for oviposition, post-oviposition period, grooming and rest.

The experiments with host manipulation have been supported by observations of oviposition in natural populations, where the variation in behavior depends both on the changes induced by the time to access the host (RoOT \& KAREIVA, 1984) and on the variation in the eggs load (OdEndAal \& RAusher, 1990). The studies about host deprivation and others closely associated studies have, in general, revealed increased amplitude in the variation of hosts and/or increased size of the aggregate, in response to deprivation and/or increased load of eggs (RosENHEIM \& Rosen, 1991).

The control and deprived females walked on the seeds, exploring them repetitively with the extremity of the antennas. BATISTE (1967) in Bruchophagus kolobovae 
(Fedosseva, 1956), KAmм \& Buttery (1986) in B. Roddi (Gussakovskiy, 1933), Kouloussis \& Katsoyannos (1994) in Eurytoma amygdali (Enderlein, 1907) and PEREIRA et al. (2003) in Bephratelloides pomorum (Fabricius, 1908) also observed this behavior in females from other species when exploring the host. According to these authors they make antennation, probably searching an ideal site to carry out oviposition. In parasitoid wasps, antennation has as function to recognize the host and distinguish whether it is parasited, as observed by POWERS \& OATMAN (1984) in Chelonuns kellieae (Marsh, 1919) and C. phthorimaeae (Gahan, 1917) and TAGAWA et al. (1985) in Apanteles glomeratus (Linnaeus, 1758). This behavior can be due to the presence of odors of the host that orientate the female for oviposition (VISSER, 1986). In E. amygdali and $B$. roddi this orientation is due to the fruit surface volatile components detected by the antennas sensillas (KAMm \& Buterry, 1986; Kouloussis \& Katsoyannos, 1994). Those experimentes were conducted under the same environmental conditions (at $30^{\circ} \mathrm{C}$ and $70 \% \mathrm{R}$. H.).

Antennation is related also to the female capacity to evaluate the degree of seed infestation and, depending on the availability, to lay eggs in the less infested, as Kouloussis \& Katsoyannos (1993) have shown in $E$. amygdali.

In this study, other behaviors as locomotion, resources exploration and copulation, were not significantly different comparing control and deprived females. One of the explanations for this fact is that the deprived females spent more time contacting the host to carry out oviposition. Time was the limitant factor concerning oviposition, since the females live nine days on average at $30^{\circ} \mathrm{C}$ and $70 \% \mathrm{R}$. H. (SARI et al., 2003). Therefore, when they found the host $P$. vulgaris, the females did not have time to select the seed and carry out oviposition adequately. Consequently, we observed more aggregates in the deprived females. They concentrated oviposition in the $1^{\text {st }}$ seed that they found at $29^{\circ} \mathrm{C}$ and 70 $\%$ R. H. (Sperandio \& Zucoloto, 2004). Rosenheim \& Rosen (1991) also observed that in the A. lingnanensis parasitoid, the females with larger loads of eggs laid larger aggregates. Those observations are also in agreement with MinkenBERg et al. (1992) and Aluja et al. (2001) that also observed that the load of eggs influences the size of the female aggregate at $26^{\circ} \mathrm{C}$ temperature and $59-72 \% \mathrm{R}$. H.

Notwithstanding, if the period of search is long and the females present limited oviposition, it is best to be highly discriminatory, since the fate of each egg can now be maximized without any "preoccupation" with time (CourTney, 1982). This was observed with the control females that spent most of the time at rest, since they did not have time as a limitant factor for their ovipositions. Thus, they could select adequately the seed, since the resources were always available. This fact coincides with the RosenheIm \& Rosen study (1991), who observed that A. lingnanensis species parasitoids with lower load of eggs and with previous experience of contact with the host, laid smaller aggregates. More properly, the decisions about the aggregate size seem fundamentally dynamic, responding to changes in the parasitoids physiology (load of eggs) and to their perception concerning the availability of the host (experience).
According to VAN Loon \& Dicke (2001), the modifications in the host selection behavior as a result of previous experiences can be observed both in the faster decision-making and in the change in preference, but the behavior sequence remains the same. The sequence of the behavioral phases and of the elements inside each phase can be completely elaborated.

The host selection behavioral sequence can be subdivided in 2 main and consecutive phases (VAN LOON $\&$ Dicke, 2001). The first, the search phase, ends with the establishment of contact with the food or with the host through visual and olfactory information, and the second, the recognition phase, ends with ingestion or oviposition. In the latter, the number of sensorial modalities and the intensity of the stimuli increase and the insects exhibit different exploratory behaviors, which involve repeated contact with the antennas, mouthparts, legs and ovipositor that carry mechanoreceptors and chemoreceptor contact sensillas (VAN LoON \& Dicke, 2001). However, the final decision of accepting or rejecting the host is not only based in sensorial information, but also in the physiological status of the insect (satiety, sexual maturity, egg maturation) and all that information is integrated in the Central Nervous System (VAN LOON \& DiCKE, 2001).

The above mentioned phases coincide with this study observations, with the exception of the contact establishment with the host that, according to Zacher (1930) apud FERREIRA (1960) occurs mainly by touch (with the palps and ovipositor) and olfaction as oviposition inducers assuring that sight has not an appreciable action. One can infer that the first phase (search) was shorter in deprived females and that the second phase (contact) was longer, since time being the limitant factor they became less selective and as the seeds were introduced several females started oviposition (pers. obs.). Besides the time, the resources availability could also determine the oviposition behavior.

These inferences are in agreement with the study of RosenHeIM \& Rosen (1991), who observed that the load of eggs influenced the intensity of the search behavior in the A. lingnanensis parasitoids, since the females with smaller load of eggs needed more time inside a foraging area to discover the host.

According to MANGEL (1987) the main qualitative forecasts about the host selection interrelate when age or the amount of mature oocytes increase, or else, when the females are deprived of the host. In that moment, they become less selective as concerns the oviposition site, because the cost of rejection of the host in relation to the reproductive success expected along the life increases. A delay to find an adequate host probably limits the available time for oviposition and can result in physiological changes (AsMAN \& Еквом, 2006); this can have consequences on the insect fecundity (TAMMARU \& JAVOIS, 2000).

ROSENHEIM \& RoSEN (1991) observed that when the parasitoids $A$. lingnanensis had a previous contact experience with the host, they laid aggregates of smaller sizes. This agrees with this study observations, where deprived females laid higher amounts of aggregated eggs in relation to the control females (in all moments of 
deprivation) (pers. obs.). With less time to lay the eggs, aggregation would be more advantageous, since the females would spare time, avoiding the recognition of each seed individually (SPERANDIO \& ZuCOLOTO, 2004).

The oviposition study in deprived and nondeprived (control) females has shown that the former stayed most of the time in contact with the host after its introduction to carry out oviposition, since the nondeprived females stayed most of the time at rest.

Oviposition of deprived females was more aggregated than that of control females, indicating a strategy related to host deprivation.

Host deprivation influences the oviposition behavior of the studied species that shows flexibility in oviposition strategies under environment changes (absence and presence of resources).

Acknowledgments. We would to thank Ana Paula dos Santos and Laércio Massocato for laboratory assistance. We declare that the experiments performed comply with current Brazilian laws.

\section{REFERENCES}

Aluja, M.; Díaz- Fleischer, F.; PAPAJ, D. R.; Lagunes, G. \& Sivinski, J. 2001. Effects of age, diet, female density, and the host resource on egg load in Anastrepha ludens and Anastrepha obliqua (Diptera: Tephritidae). Journal of Insect Physiology 47(9):975-988

Asman, K. \& Eквом, B. 2006. Responses of ovipositing moths to host plant deprivation: life history aspects and implications for intercropping. Agricultural and Forest Entomology 8:213-219.

Batiste, W. C. 1967. Biology the trefoil seed chalcid Bruchophaghus kolobovae Fedoseeva (Hymenoptera: Eurytomidae). Hilgardia 38:427-469.

Carvalho, R. P. L. \& Rossetto, J. C. 1968. Biologia de Zabrotes subfasciatus (Bohemann) (Coleoptera, Bruchidae). Revista Brasileira de Entomologia 13:105-117.

Cope, J. \& Fox, C. W. 2003. Oviposition decisions in the seed beetle, Callosobrucus maculatus (Coleoptera, Bruchidae): effects of seed size on superparasitism. Journal of Stored Products Research 39:355-365.

Courtney, S. P. 1982. Coevolution of pierid butterflies and their cruciferous foodplants. V. Habitat selection, community structure and speciation. Oecologia 54:101-107.

Credland, P. F. \& Dendy, J. 1992. Intraespecific variation in bionomic characteres of the Mexican bean weevil, Zabrotes subfasciatus. Entomologia Experimentalis et Applicata 65:39-47.

Dendy, J. \& Credland, P. F. 1991. Development, fecundity and egg dispersion of Zabrotes subfasciatus. Entomologia Experimentalis et Applicata 59:9-17.

Ferreira, A. M. 1960. Subsídios para o estudo de uma praga de feijão (Zabrotes subfasciatus Boh. -Coleoptera, Bruchidae) dos climas tropicais. Garcia de Orta 8(3):559-581.

FitT, G. P. 1986. The influence of a shortage of hosts on the specificity of oviposition behaviour in species of Dacus (Diptera, Tephritidae). Physiological Entomology 11:133-143.

Fleury, F. \& Boulétreau, M. 1993. Effects of temporary host deprivation on the reproductive potential of Trichogramma brassicae. Entomologia Experimentalis et Applicata 68:203-210.

HAines, C. P. 1991. Insects and arachnids of tropical stored products: Their biology and identification. $2^{\text {nd }}$. edition. Kent, Natural Resources Institute. 246 p.

Harris, M. O. \& Miller, J. R. 1988. Host-acceptance behaviour in an herbivorous fly, Delia antiqua. Journal of Insect Physiology 34:179-190.

Hsiao, T. H. 1985. Feeding behavior. In: Kerkut, G. A. \& Gilbert, L. I. eds. Comprehensive Insect Physiology, Biochemistry and Pharmacology IV. Oxford, Pergamon. p.471-512.
Johnson, C. D. 1989. Adaptative radiation of Acanthoscelides in seeds: examples of legume-bruchid interactions. In: StiRton, C. H. \& Zarucchi, J. L. eds. Advances in legume biology. Monographs in Systematic Botany 29:747-779.

Kamm, J. A. \& Buttery, R. G. 1986. Ovipositional behavior of the alfafa seed chalcid volatile components of alfafa. Environmental Entomology 15:388-391.

Kouloussis, N. A. \& Katsoyannos, B. I. 1993. Egg distribution patterns in the almond seed wasp, Eurytoma amygdali. Entomologia Experimentalis and Applicata 66:31-38. 1994. Adult response the almond seed wasp, Eurytoma amygdali, to chemicals from its host and certain nonhosts. Entomologia Experimentalis and Applicata 73:211-220.

Mangel, M. 1987. Oviposition site selection and clutch size in insects. Journal of Mathematical Biology 25:1-22.

MaYhew, P. J. 1997. Adaptive patterns of host-plant selection by phytophagous insects. Oikos 79:417-428.

MeIK, J. \& DobIE, P. 1986. The ability of Zabrotes subfasciatus to attack cowpeas. Entomologia Experimentalis et Applicata 42:151-158.

Minkenberg, O. P. J. M.; Tatar, M. \& Rosenheim, J. A. 1992. Egg load as a major source of variability in insect foraging and oviposition behavior. Oikos 65:134-142.

Odendaal, F. J. \& Rausher, M. D. 1990. Egg load influences search intensity, host selectivity, and clutch size in Battus philenor butterflies. Journal of Insect Behavior 3:183-193.

PAJni, H. R. \& JabBAL, A. 1986. Some observations of Zabrotes subfasciatus (Boh.) (Bruchidae: Coleoptera). Research Bulletin of he Panjab University Science 37:11-16.

Pereira, M. J. B.; Anjos, N. \& Eiras, A. E. 2003. Oviposição da broca-da-semente de graviola Bephratelloides pomorum (Fabricius, 1908) (Hymenoptera: Eurytomidae). Arquivos do Instituto Biológico 70(2):221-224.

Powers, N. R. \& OAtman, E. R. 1984. Biology and temperature responses of Chelonus kellieae and Chelonus phthorimaeae (Hymenoptera: Braconidae) and their host the potato tuberworm Phthorimaea operculella (Lepidoptera: Gelechiidae). Hilgardia 52:1-32.

Renwick, J. A. A. 1989. Chemical ecology of oviposition in phytophagous insects. Experientia 45:223-228.

Root, R. B. \& Kareiva, P. M. 1984. The search for resources by cabbage butterflies (Pieris rapa): ecological consequences and adaptative significance of Markovian movements in a patchy environment. Ecology 65:147-165.

Rosenheim, J. A. \& Rosen, D. 1991. Foraging and oviposition decisions in the parasitoid Aphytis lingnanensis: distinguishing the influences of egg load and experience. Journal of Animal Ecology 60:873-893.

SADEGH, H. \& Gilbert, F. 2000. The effect of egg load and host deprivation on oviposition behaviour in aphidophagous hoverflies. Ecological Entomology 25:101-108.

Sari, L. T.; Ribeiro-Costa, C. S. \& Pereira, P. R. V. 2003. Aspectos biológicos de Zabrotes subfasciatus (Bohemann, 1833) (Coleoptera, Bruchidae) em Phaseolus vulgaris L., cv. Carioca (Fabaceae), sob condições de laboratório. Revista Brasileira de Entomologia 47(4):621-624.

Singer, M. C. 1986. The definition and measurement of oviposition preference in plant-feeding insects. In: Miller, J. P. \& Miller, T. A. eds. Insect-Plant Interactions. New York, Springer. p. 65-94.

Southgate, B. J. 1979. Biology of the Bruchidae. Review of Entomology 24(1):449-473.

Sperandio, L. A. A. \& Zucoloto, F. S. 2004. Oviposition behavior of Zabrotes subfasciatus females (Coleoptera, Bruchidae) under conditions of host deprivation. Iheringia, Série Zoologia, 94(3):315-319.

SzEnTESI, A. 2003. Resource assessment and clutch size in the bean weevil, Acanthoscelides obtectus. Pest Management Science 59:431-436.

Tagawa, J.; Asano, S. \& Ohtsubo, T. 1985. Influence of age on the mating behavior of the braconid wasp Apanteles glomeratus. Applied Entomology and Zoology 20:227-230.

TAmmaru, T. \& Javois, J. 2000. Responses of ovipositing moths (Lepidoptera: Geometridae) to host plant deprivation: lifehistory aspects and implications for population dynamics. Environmental Entomology 29:1002-1010. 
Teixeira, I. R. V. \& Zucoloto, F. S. 2003. Seed suitability and oviposition behaviour of wild and selected populations of Zabrotes subfasciatus (Boheman) (Coleoptera, Bruchidae) on different hosts. Journal of Stored Products Research 39:131-140.

UTiDA, S. 1967. Collective oviposition and larval aggregation in Zabrotes subfasciatus (Boh.) (Coleoptera, Bruchidae). Journal of Stored Products Research 2:315-322.
VAn Loon, J. J. A. \& Dicke, M. 2001. Sensory ecology of arthropods utilizing plant infochemicals. In: BARTH, F. G. \& SCHimidT, A eds. Ecology of Sensing. Berlin, Springer-Verlag. p.253-270.

VISSER, J. H. 1986. Host odor perception in phytophagous insects. Annual Review Entomology 31:121-144.

YANG, R. L. \& HoRng, S. B. 2002. Host size discrimination and oviposition behavior of the seed beetle, Callosobruchus maculatus. Formosan Entomologist 22:343-357. 